\title{
ANALISIS PENENTUAN POLA PRODUKSI UNTUK MEMINIMALISASI BIAYA PRODUKSI PADA HOME INDUSTRI KERIPIK PISANG KHARISMA DI BANDAR LAMPUNG
}

\author{
Iskandar Ali Alam \\ Fakultas Ekonomi dan Bisnis Universitas Bandar Lampung \\ Jl. Z.A Pagar Alam No. 26 Labuhan Ratu Bandar Lampung 35142 \\ Email: iskandar.aa@ubl.ac.id \\ Neliedia \\ Fakultas Ekonomi dan Bisnis Universitas Bandar Lampung \\ Jl. Z.A Pagar Alam No. 26 Labuhan Ratu Bandar Lampung 35142 \\ Email: neliedia17@gmail.com
}

\begin{abstract}
ABSTRAK
Penelitian ini bertujuan untuk mengetahui pola produksi yang diterapkan oleh home industri keripik pisang Kharisma, dan untuk mengetahui perbandingan pola produksi konstan, bergelombang dan moderat. Menentukan pola produksi sebaiknya digunakan untuk meminimalkan biaya tambahan. Metode pengumpulan data menggunakan metode observasi dengan cara pengamatan langsung pada obyek penelitian, dan wawancara dengan pemilik perusahaan.

Teknik analisis data menggunakan analisis biaya tambahan dengan melihat pola permintaan produk, menghitung biaya tambahan yang mencakup biaya simpan, biaya perputaran tenaga kerja, biaya lembur serta biaya sub kontrak, membandingkan biaya tambahan dari pola produksi yang diterapkan dengan pola produksi lain dan menyimpulkan pola produksi yang efisien.

Setelah menganalisis biaya tambahan pada home industri keripik pisang Kharisma terdapat tiga

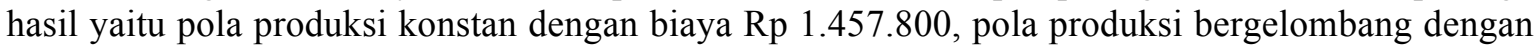
biaya $\mathrm{Rp} 403.500$, dan pola produksi moderat dengan biaya $\mathrm{Rp}$ 1.402.900. Berdasarkan hasil penelitian tersebut dapat disimpulkan bahwa pola produksi bergelombang adalah pola produksi yang paling tepat karena memiliki biaya tambahan rendah sehingga mampu meminimalkan biaya produksi.
\end{abstract}

Kata kunci : Pola Produksi Konstan, Pola Produksi Bergelombang, Pola Produksi Moderat.

\section{ABSTRACT}

This study aims to determine the production patterns applied by the home industry of banana chips Kharisma, and to find out the comparison of constant, corrugated and moderate production patterns. Determining production patterns should be used to minimize incremental cost. The method of data collection uses the observation methode by direct observation of the object of research, and interviews with the owner of the company.

The data analysis technique uses incremental cost analysis by looking at product demand patterns, calculating additional costs that include storage costs, labor turnover costs, overtime costs and sub-contract costs, comparing the incremental cost of applied patterns with other production patterns and concluding production patterns efficient.

After analyzing the incremental cost in the home industry of banana chips Kharisma there are three results, namely constant production pattern with a cost of Rp 1.457.800, corrugated production pattern at a cost of $R p$ 403.500, and moderate productions pattern at cost of $R p$ 1.402.900. Based on the result of these studies it can be concluded that the corrugated production pattern is the most appropriate production pattern applied because it has a low incremental cost so as to minimize production costs.

Keywords : Constant Production Pattern, Corrugated Production Pattern, Moderate Production Pattern. 


\section{PENDAHULUAN}

Home industri adalah rumah usaha produk barang atau dapat juga disebut perusahaan kecil. Dikatakan sebagai perusahaan kecil karena jenis kegiatan ekonomi tersebut dipusatkan di rumah. Tidak menutup kemungkinan kalau perusahaan kecil ini juga dapat menjadi perusahaan besar.

Home industri keripik pisang Kharisma adalah sebuah industri rumahan yang memproduksi keripik pisang sebagai oleh-oleh khas Lampung. Home industri ini sudah berdiri sejak tahun 1992 dan bertempat di Bandar Lampung.

Dalam proses produksi perlu diadakan perencanaan produksi. Salah satu rencana produksi yang paling penting adalah perencanaan pola produksi yang akan dijalankan. Selama ini, home industri keripik pisang Kharisma memproduksi keripik nya hanya sesuai dengan target penjualan. Oleh karena itu penulis ingin mencari pola produksi yang tepat agar keuntungan yang diperoleh pun dapat maksimal, mengeluarkan biaya produksi yang minimal dan segala sesuatu menjadi efektif dan efisien.

Home industri keripik pisang Kharisma tentu saja menjadikan pisang sebagai bahan baku. Pisang adalah buah yang cepat sekali matang, apabila pisang menjadi matang, pisang tersebut tidak dapat diserut. Home industri ini juga menjual keripik pisang nya dengan 5 rasa seperti original (asin), manis, balado, cokelat dan cappucino. Khususnya rasa balado, cokelat dan cappucino tersebut mengunakan bumbu yang dibeli di pasaran. Bumbu adalah bahan yang mudah sekali lembab, apabila lembab tentu tidak dapat dipakai lagi karena menggumpal. Karena keripik pisang Kharisma masih home industri, tempat menyimpan pun masih terbatas.

Adanya fluktuasi penjualan memaksa manajer operasional mengambil keputusan yang rasional untuk mencapai target perusahaan yang telah ditetapkan. Perusahaan harus mengambil langkah yang tepat guna, salah satunya dengan menetapkan pola produksi tepat agar kelangsungan hidup perusahaan tetap berjalan dan dapat bersaing dengan perusahaan lain.
Data Penjualan

Home Industri Keripik Pisang Kharisma

Tahun 2015-2017

(dalam satuan bungkus)

\begin{tabular}{|l|c|c|c|}
\hline \multirow{2}{*}{ Bulan } & \multicolumn{3}{|c|}{ Tahun } \\
\cline { 2 - 4 } & $\mathbf{2 0 1 5}$ & $\mathbf{2 0 1 6}$ & $\mathbf{2 0 1 7}$ \\
\hline Januari & 770 & 980 & 515 \\
\hline Februari & 550 & 690 & 630 \\
\hline Maret & 755 & 850 & 615 \\
\hline April & 610 & 805 & 560 \\
\hline Mei & 455 & 980 & 360 \\
\hline Juni & 600 & 765 & 890 \\
\hline Juli & 670 & 1100 & 390 \\
\hline Agustus & 630 & 640 & 610 \\
\hline September & 500 & 690 & 945 \\
\hline Oktober & 660 & 750 & 665 \\
\hline November & 410 & 385 & 560 \\
\hline Desember & 740 & 745 & 800 \\
\hline Jumlah & $\mathbf{7 . 3 5 0}$ & $\mathbf{9 . 3 8 0}$ & $\mathbf{7 . 5 4 0}$ \\
\hline
\end{tabular}

Untuk dapat menentukan pola produksi yang tepat, kita harus terlebih dahulu menghitung besarnya "Incremental Cost Analysis" yaitu tambahan biaya yang akan terjadi bila perusahaan memilih suatu alternatif keputusan tertentu. Analisis ini akan memudahkan perusahaan untuk menentukan pola produksi yang tepat yaitu terpenuhinya target penjualan dengan biaya minimal. Pola produksi yang dipilih disini merupakan pola produksi yang mendapatkan penghematan biaya produksi dalam perusahaan yang bersangkutan.

Melalui penerapan pola produksi yang tepat diharapkan perusahaan dapat merencanakan kebutuhan tenaga kerja, bahan baku, fasilitas lain secara tepat. Apabila terlalu sedikit tenaga kerja tentu saja perusahaan akan mengalami kesulitan dalam memenuhi permintaan dari konsumen yang mengakibatkan mengurangnya kepercayaan konsumen terhadap perusahaan. Sama halnya dengan terlalu banyak bahan baku, tentu saja perusahaan akan menanggung biaya yang lebih besar karena bahan baku tidak dapat diproduksi dengan maksimal karena penawaran lebih besar dibandingkan dengan permintaan apabila terjadi penurunan permintaan pada konsumen. Apabila perusahaan dapat menentukan pola produksi yang tepat maka hal-hal tersebut dapat ditekan karena perusahaan dapat merencanakannya 
sesuai kapasitas yang dimiliki sehingga biaya juga dapat ditekan.

Menurut Basu Swasta dan Ibnu Sukotjo (2002:280) produksi adalah pengubahan bahanbahan dari sumber-sumber menjadi hasil yang dinginkan oleh konsumen.

Menurut Zulian Yamit (2003:5) produksi adalah kegiatan untuk mengolah input melalui proses transformasi atau pengubahan sedemikian rupa sehingga menjadi output yang berupa barang dan jasa.

Menurut Basu Swasta dan Ibnu Sukotjo (2002:198) fungsi produksi adalah menciptakan barang atau jasa sesuai dengan kebutuhan masyarakat pada waktu harga dan jumlah yang tepat.

Menurut T. Hani Handoko (2003:3) manajemen produksi dan operasi merupakan usaha-usaha pengelolaan secara optimal penggunaan sumber daya-sumber daya (disebut faktor-faktor produksi) tenaga kerja, mesinmesin, peralatan, bahan mentah dan sebagainya dalam proses transformasi bahan mentah dan tenaga kerja menjadi berbagai produk dan jasa.

Menurut Agus Ahyari (2003:46) manajemen produksi merupakan suatu proses manajemen yang meliputi perencanaan, pengorganisasian, pengarahan, pengkoordinasian serta pengendalian yang diterapkan dalam bidang produksi didalam sebuah perusahaan.

Menurut Agus Ahyari (2003:13) perencanaan produksi mempunyai arti suatu rencana dari apa dan berapa jumlahnya masingmasing yang segera akan diproduksikan pada periode yang akan datang. Jangka waktu pakai dari perencanaan produksi adalah satu tahun.

Menurut Sofjan Assauri (2008:181) perencanaan produksi (prduction planning) adalah perencanaan dan pengorganisasian sebelumnya mengenai orang-orang, bahanbahan, mesin-mesin dan peralatan lain serta modal yang dipergunakan untuk memproduksi barang-barang pada suatu periode tertentu di masa depan sesuai dengan yang diperkirakan atau diramalkan.

Menurut Sofjan Assauri (2008:182) tujuan perencanaan produksi adalah sebagai berikut : untuk mencapai tingkat atau level keuntungan (profit) yang tertentu untuk menguasai pasar tertentu, sehingga hasil atau output perusahaan ini tetap mempunyai pangsa pasar (market share) tertentu, untuk mengusahakan supaya perusahaan pabrik ini dapat bekerja pada tingkat efisiensi tertentu, untuk mengusahakan dan mempertahankan supaya pekerjaan dan kesempatan kerja yang sudah ada tetap pada tingkatnya dan berkembang, untuk menggunakan sebaik-baiknya (efisien) fasilitas yang sudah ada pada perusahaan yang bersangkutan. Menurut Indriyo Gitosudarmo (2007:62) pentingnya diadakan suatu perencanaan karena meliputi usaha untuk menetapkan tujuan atau memformulasikan tujuan yang dipilih untuk dicapai, maka perencanaan dapat membedakan arah bagi setiap kegiatan produksi dengan jelas. Dengan adanya kejelasan tersebut maka kegiatan akan dapat dilaksanakan secara efisien dan efektivitas setinggi mungkin.

Menurut Sofjan Assauri (2008:183) jenisjenis perencanaan produksi adalah sebagai berikut.

Perencanaan produksi jangka panjang adalah penentuan tingkat kegiatan produksi lebih daripada satu tahun, dan biasanya sampai dengan lima tahun mendatang, dengan tujuan untuk mengatur pertambahan kapasitas peralatan mesin-mesin, ekspansi pabrik dan pengembangan produk (product development).

Perencanaan produksi jangka pendek adalah penentuan kegiatan produksi yang akan dilakukan dalam jangka waktu satu tahun mendatang atau kurang, dengan tujuan untuk mengatur penggunaan tenaga kerja, persediaan bahan dan fasilitas produksi yang dimiliki perusahaan pabrik. Oleh karena perencanaan produksi jangka pendek berhubungan dengan pengaturan operasi jangka pendek, maka perencanaan ini disebut juga dengan perencanaan operasional.

Menurut Zulian Yamit (2003:84) pola produksi sebagai distribusi dari produksi tahunan kedalam periode-periode yang lebih kecil, seperti bulanan atau triwulan untuk mengantisipasi rencana penjualan.

Menurut Agus Ahyari (2003:184) pola produksi adalah sebagai distribusi atau pembagi dari produksi tahunan kedalam periode yang 
lebih kecil misalnya : bulan, minggu atau unit waktu yang lain.

Menurut Zulian Yamit (2003:84) untuk mengantisipasi pola penjualan yang akan datang terdapat tiga alternatif pola produksi yang dapat dilakukan perusahaan, yaitu:

Pola produksi konstan yaitu jumlah produksi yang dihasilkan selalu sama dalam setiap satuan waktu. Sebagai konsekwensi dari jumlah adanya produksi yang sama atau relatif sama, maka untuk menutup adanya kenaikan jumlah penjualan produk, perusahaan akan mengambilnya dari persediaan barang jadi, sehingga jumlah persediaan barang jadi dalam perusahaan akan berkurang. Sebaliknya apabila pada suatu waktu tertentu jumlah penjualan produk perusahaan mengalami penurunan, maka kelebihan produksi atas penjualan akan dimasukkan ke dalam gudang persediaan barang jadi, sehingga persediaan barang jadi akan bertambah. Oleh karena itu jumlah produksi dari waktu ke waktu pada pola produksi konstan adalah sama atau relatif sama, maka pola produksi semacam ini sering disebut sebagai pola produksi yang stabil (lebih mementingkan adanya stabilitas produksi).

Pola produksi bergelombang adalah jumlah produksi setiap satuan waktu mengikuti fluktuasi permintaan (Zulian Yamit, 1998:77). Akibatnya pola ini berpengaruh pada persediaan barang jadi yang akan relatif sama setiap waktunya yang disebabkan perubahan jumlah penjualan akan diikuti langsung dengan perubahan tingkat produksi. Pola produksi ini dapat dikatakan sebagai pola produksi yang menitikberatkan kepada stabilitas persediaan dimana tidak akan ada penumpukan barang jadi.

Pola produksi moderat yaitu jumlah produksi dalam beberapa periode tertentu konstan dan dalam periode tertentu mengalami kenaikan untuk konstan kembali. Dengan kata lain perubahan penjualan produk perusahaan setiap waktunya akan ditutup bersama-sama oleh perubahan persediaan barang jadi dan kegiatan produksi perusahaan. Dalam pola produksi ini kenaikan atau penurunan tingkat penjualan setiap waktunya tidak begitu akan berpengaruh, baik terhadap tingkat produksi perusahaan maupun tingkat persediaan barang jadi.

Dengan menggunakan pola produksi moderat keuntungan dan kerugian pada pola produksi sebelumnya akan saling menutup. Keburukan pola produksi konstan akan tertutupi oleh keunggulan pola produksi bergelombang. Begitu sebaliknya keburukan pola produksi bergelombang akan tertutupi oleh keunggulan pola produksi konstan. Dengan kata lain pola produksi moderat ini merupakan alternatif jalan tengah antara pola produksi sebelumnya. Sedangkan kelemahannya adalah kemungkinan timbul semua biaya tambahan dalam biaya produksinya.

Faktor-faktor yang mempengaruhi pola produksi adalah pola penjualan, pola biaya, biaya perputaran tenaga kerja, biaya simpan, biaya lembur, biaya sub kontrak, dan kapasitas produksi.

Tingkat kemampuan perusahaan dalam memenuhi kebutuhan pasar atau konsumen (Gitosudarmono, 2002:173). Kapasitas perusahaan dipengaruhi oleh berbagai faktor antara lain jumlah karyawan, jumlah mesin, jumlah jam kerja.

Menurut Mulyadi (2005:8) biaya adalah pengorbanan sumber ekonomi yang diukur dalam satuan uang yang telah terjadi atau yang kemungkinan akan terjadi untuk tujuan tertentu. Menurut Sofjan Assauri (2008:339) biaya produksi adalah pengeluaran yang tidak dapat dihindarkan, tetapi dapat diperkirakan dalam penghasilan suatu barang. Besarnya biaya produksi merupakan besarnya pembebanan

yang diperhitungkan atas pemakaian factor-

faktor produksi, yang berupa bahan, tenaga kerja serta mesin dan peralatan untuk menghasilkan suatu produk tertentu.

\section{METODE PENELITIAN}

Jenis penelitian yang digunakan dalam penelitian ini adalah library research (penelitian kepustakaan), field research (penelitian lapangan), developmental research (penelitian pengembangan), dan verifikatif research (penelitian pengujian).

Dalam penelitian ini desain yang digunakan adalah penelitian deskriptif yaitu prosedur atau cara pemecahan masalah dengan 
menggambarkan keadaan yang sedang berlangsung pada saat sekarang berdasarkan fakta-fakta yang tampak sebagaimana adanya.

Teknik pengumpulan data yang digunakan dalam penelitian ini adalah observasi, komunikasi, dan studi dokumentasi.

Jenis dan sumber data yang digunakan dalam penelitian ini adalah data primer. Data primer adalah data yang diperoleh langsung dari sumbernya oleh orang yang melakukan penelitian.

\section{PEMBAHASAN}

Perencanaan produksi merupakan kebutuhan penting sebagai keuputusan manajerial. Perencanaan produksi yang baik diharapkan akan dapat menekan biaya produksi maupun biaya tambahan yang pada akhirnya akan menambah laba atau mengurangi kerugian. Perencanaan produksi dapat dilakukan melalui perencanaan jangka panjang dan jangka pendek. Perencanaan jangka pendek adalah penentuan kegiatan produksi yang akan dilakukan dalam jangka waktu satu tahun atau kurang. Perencanaan jangka pendek ini menekankan pada pengaturan operasional yaitu pengaturan produksi. Perencanaan produksi jangka panjang adalah penentuan kegiatan produksi lebih dari satu tahun. Tujuan perencanaan jangka panjang adalah untuk perencanaan pengadaan alat produksi, sumber daya manusia, ekspansi pemasaran, penambahan modal dan lain sebagainya.

Penelitian ini menitik beratkan pada perencanaan produksi jangka pendek yaitu untuk menentukan pola produksi yang lebih sesuai untuk perusahaan. Berdasarkan penelitian yang dilakukan, ternyata alternatif pemilihan pola produksi yang paling menguntungkan bagi perusahaan adalah pola produksi bergelombang.

Persediaan adalah salah satu faktor penting dalam industri dan perdagangan. Persediaan yang tinggi menyebabkan berhentinya modal kerja. Modal kerja akan menimbulkan biaya penyimpanan, antara lain biaya peluang. Apabila pada waktu bunga bank tinggi, banyak biaya peluang yang hilang.

Hasil Analisis Biaya Tambahan

Home Industri Keripik Pisang Kharisma

\begin{tabular}{|l|c|c|c|}
\hline \multicolumn{1}{|c|}{$\begin{array}{c}\text { Jenis } \\
\text { Biaya }\end{array}$} & $\begin{array}{c}\text { Pola } \\
\text { Produksi } \\
\text { Konstan }\end{array}$ & $\begin{array}{c}\text { Pola } \\
\text { Produksi } \\
\text { Bergelom } \\
\text { bang }\end{array}$ & $\begin{array}{c}\text { Pola } \\
\text { Produksi } \\
\text { Moderat }\end{array}$ \\
\hline $\begin{array}{l}\text { Biaya } \\
\text { Simpan }\end{array}$ & 1.110 .000 & - & 910.000 \\
\hline $\begin{array}{l}\text { Biaya } \\
\text { Sub } \\
\text { Kontrak }\end{array}$ & 347.800 & - & 267.900 \\
\hline $\begin{array}{l}\text { Biaya } \\
\text { Lembur }\end{array}$ & - & - & - \\
\hline $\begin{array}{l}\text { Biaya } \\
\text { Perputara } \\
\text { n Tenaga } \\
\text { Kerja }\end{array}$ & - & 403.500 & 225.000 \\
\hline Jumlah & $\mathbf{1 . 4 5 7 . 8 0 0}$ & $\mathbf{4 0 3 . 5 0 0}$ & $\mathbf{1 . 4 0 2 . 9 0 0}$ \\
\hline
\end{tabular}

Berdasarkan hasil analisis diatas diketahui bahwa pola produksi bergelombang mempunyai biaya tambahan terendah yaitu sebesar Rp 403.500, biaya tambahan ini timbul karena adanya perputaran tenaga kerja yang disebabkan oleh peningkatan dan penurunan jumlah produksi yang sangat tinggi setiap periodenya. Akan tetapi biaya tambahan pada pola produksi bergelombang ini relatif lebih kecil dibandingkan dengan pola produksi konstan yang memiliki biaya tambahan sebesar $\mathrm{Rp} 1.457 .800$ dan pola produksi moderat sebesar Rp 1.402.900 yang disebabkan oleh adanya biaya penyimpanan yang cukup besar dan juga adanya biaya sub kontrak karena jumlah barang yang diproduksi tidak mampu memenuhi jumlah permintaan pasar.

\section{KESIMPULAN DAN SARAN Kesimpulan}

Setelah menganalisis biaya tambahan pada home industri keripik pisang Kharisma terdapat tiga hasil yaitu pola produksi konstan dengan biaya Rp 1.457.800, pola produksi bergelombang dengan biaya Rp 403.500, dan pola produksi moderat dengan biaya $\mathrm{Rp}$ 1.402.900.

Berdasarkan hasil penelitian tersebut dapat disimpulkan bahwa pola produksi bergelombang adalah pola produksi yang paling tepat diterapkan pada home industri keripik pisang Kharisma karena memiliki biaya tambahan rendah yaitu $\mathrm{Rp} 403.500$ per tahun 
sehingga mampu meminimalkan biaya produksi.

\section{Saran}

Berdasarkan penelitian yang dilakukan, maka peneliti menyarankan untuk memenuhi permintaan konsumen atau pasar yang berfluktuasi sebaiknya perusahaan menerapkan pola produksi bergelombang. Dengan terpenuhinya permintaan, perusahaan akan menjalin hubungan yang baik dengan konsumen. Selain itu, dengan pola produksi bergelombang yang juga menekan biaya simpan maka resiko barang rusak akibat penyimpanan akan semakin kecil. Perusahaan hendaknya melakukan peramalan permintaan terhadap produknya dengan memakai metode yang paling optimal atau memiliki tingkat kesalahan yang paling kecil yaitu menggunakan model matematis dengan pendekatan kuantitatif yang berdasarkan data historis yang ada. Kebijakan pemilihan pola produksi yang dilakukan home industri keripik pisang Kharisma hendaknya terlebih dahulu melihat pola biaya, pola peramalan, dan kapasitas produksi maksimal yang dimiliki sehingga diperoleh pola produksi yang optimal untuk meminimalisasi biaya produksi.
DAFTAR PUSTAKA

Ahyari, Agus. 2003. Manajemen Produksi Perencanaan Sistem Produksi. Edisi Keempat. BPFE- Yogyakarta.

Assauri Sofjan. 2008. Manajemen Produksi dan Operasi, Edisi Revisi. FE, Universitas Indonesia.

Basu Swastha dan Ibnu Sukotjo. (2002). Pengantar Bisnis Modern. Edisi Keenam,Yogyakarta: Liberty.

Gitosudarmo, Indriyo. 2007. Manajemen Operasi. Edisi Ketiga. BPFEYogyakarta.

Handoko T. Hani, 2003. Dasar-Dasar Manajemen Produksi dan Operasi, Edisi Pertama, Cetakan Ke Dua Belas BPFE, Yogyakarta.

Moleong, Lexy J. (2007) Metodologi Penelitian Kualitatif, Penerbit PT Remaja Rosdakarya Offset, Bandung

Mulyadi. 2005. Akuntansi Biaya. Edisi Kelima. UGM. Yogyakarta.

Sugiyono, 2010. Statistika Untuk Penelitian. Cetakan Ketujuh Belas. Alfabeta, Bandung

Sumarni Murti - John Suprihanto. 2003. Pengantar Bisnis, Edisi Ke Empat, Liberty Yogyakarta.

Wulan, Sapmaya. 2014. Metode Penelitian. Universitas Bandar Lampung. Lampung.

Yamit, Zulian. 2003. Manajemen Produksi dan Operasi. Edisi Keempat. Ekonisia FE Universitas Islam Indonesia. Yogyakarta. 